\title{
O TRAVESTIMENTO DO CORPO E DA escritura em Severo Sarduy
}

\author{
THE TRANSVESTISM OF THE BODY AND THE
} LITERARY TEXTS IN SEVERO SARDUY

\section{Maria Cristina Chaves Carvalho}

Universidade Federal do Espírito Santo

Vitória - ES

\begin{abstract}
Resumo
Este trabalho se propóe a realizar uma breve análise do romance Cobra, de Severo Sarduy, buscando examinar a existência de uma prática barroca nessas escrituras, seguindo a vertente neobarroca, responsável pela revitalização de traços do barroco na contemporaneidade. A expressão da anamorfose, uma rubrica das artes plásticas, deverá ser associada a uma forma modificada da escrita, que pode ser reconfigurada como um processo de criação do romance referido. A figura do travesti será investigada devido à sua aparência híbrida, que se configura em gestos e cores de um corpo que é também tecido. Nesse sentido, será realizada uma associação entre a imagem desse corpo sujeito a metamorfoses e o corpo do texto, o qual converge para uma escrita andrógina. O travestimento do corpo da palavra, conforme Severo Sarduy, será perceptível nas tramas do texto através de procedimentos de escrita que visam à encenação.
\end{abstract}

Palavras-chave: Severo Sarduy, Literatura Cubana, neobarroco, anamorfose, travestimento.

\section{Abstract}

This work presents a brief analysis of Severo Sarduy's novel Cobra, with the aims of examining the existence of a Baroque practice in this literary work, which follows a Neo-Baroque perspective that is responsible for the revitalization of Baroque traits in contemporaneity. The expression of anamorphosis, a term borrowed from the fine arts, will be linked to a modified form of writing, which can be viewed as the process of creation of Cobra. The image of the transvestite, present in the novel. will be investigated for his hybrid appearance, which is shaped in the gestures and colors of a body that has also been intricately woven. In this regard, an association

\section{Resumen}

Este trabajo propone un breve análisis de la novela Cobra, de Severo Sarduy, buscando examinar la existencia de una práctica barroca en esos textos, que sigue la vertiente neobarroca, responsable por la revitalización de líneas del barroco en la contemporaneidad. La expresión de la anamorfosis, una rúbrica de las artes plásticas, debe asociarse a una forma modificada de la escritura, que puede ser reconfigurada como un proceso de creación de la novela. La imagen del travestido, presente en la obra, debe ser investigada por su apariencia híbrida, que se configura en los gestos y colores de un cuerpo que también es tejido. En ese sentido, se logará una asociación 
will be made between the image of this body which is subject to metamorphosis and the textual body, which converges towards a kind of androgynous writing. According to Sarduy, the transvestism of the body of the word will be perceptible in the plots of the texts through the writing procedures that pursue a staging.

Keywords: Severo Sarduy, Cuban Literature, Neo-Baroque, anamorphosis, transvestism. entre la imagen de ese cuerpo sujeto a las metamorfosis y el cuerpo del texto, el cual converge en una escritura andrógina. Según Severo Sarduy, el travestimiento del cuerpo de la palabra será perceptible en las tramas de los textos a través de procedimientos de escritura que buscan una escenificación.

Palabras claves: Severo Sarduy, Literatura cubana, neobarroco, anamorfosis, travestimiento.

$O$ texto que o senhor escreve tem de me dar prova de que ele me deseja. Essa prova existe: é a escritura. A escritura é isto: a ciência das fruiçóes da linguagem, seu Kama-Sutra (desta ciência, só há um tratado: a própria escritura).

Roland Barthes. O prazer do texto, 2006, p. 11

De acordo com Roland Barthes, a escritura é uma nova forma de denominar um texto literário, e este deve ser compreendido também como o resultado do trabalho do leitor. Assim, cabe ao leitor explorar a escritura a fim de ler o que se encontra na superfície do texto e o que se oculta em seu interior, em suas entrelinhas. Segundo o autor, há uma diferença entre texto de prazer e texto de fruição: texto de prazer é aquele que agrada, satisfaz, "dá euforia", é o texto proveniente da cultura, que náo está relacionado à ruptura, mas sim "ligado a uma prática confortável da leitura" (BARTHES, 2006: 20), enquanto texto de fruição

[...] é aquele que póe em estado de perda, aquele que desconforta (talvez até um certo enfado), faz vacilar as bases históricas, culturais, psicológicas do leitor, a consistência de seus gostos, de seus valores e de suas lembranças, faz entrar em crise sua relação com a linguagem (BARTHES, 2006: 20-21).

Em seu conhecido estudo, O prazer do texto, Barthes analisa o prazer sensual do texto, por parte de quem escreve, sem que este tenha medo de expor seus anseios e desejos, visando ao jogo que se estabelece entre o texto e o leitor, sujeito prestigiado pelo autor, que nunca o considera passivo e apático diante do texto. Barthes evidencia esse jogo sensual, revelado no texto em função de sua plenitude criativa, o qual remete ao ato da sua fruição, pelo leitor.

A partir da leitura de um texto, conforme Barthes, entramos em um campo de prazer, na linguagem, e é desse modo que pretendemos fruir o 
romance Cobra, de Severo Sarduy. Trata-se de um romance sedutor, que atrai o leitor para um jogo sensual: é um texto de fruição que impele o leitor a persegui-lo, como se a leitura provocasse o desejo de possuí-lo. Essa fruição está relacionada ao que Barthes chama de "dialética do desejo", por remeter ao espaço da fruição e por estar associada à ideia de jogo: "não é a 'pessoa' do outro que me é necessária, é o espaço: a possibilidade de uma dialética do desejo, de uma imprevisáo do desfrute: que os dados não estejam lançados, que haja jogo" (BARTHES, 2006: 9).

Ao discorrer sobre o romance Cobra, Barthes se refere a "outra margem", outra felicidade que se encontra no desejo de querer sempre mais, desejo de palavra como desejo de festa: "Em Cobra, de Severo Sarduy (traduzido [para o francês] por Sollers e pelo autor), a alternância é a de dois prazeres em estado de sobrelanço; a outra margem é a outra felicidade: mais, mais, mais ainda!, ainda mais outra palavra, mais outra festa" (BARTHES, 2006: 13-14). ${ }^{1}$ De acordo com Barthes, a reconstrução da língua se dá num lugar de prazer, como no texto de ficção de Sarduy, em que

[...] o autor (o leitor) parece dizer-lhes: amo a vocês todos (palavras, giros, frases, adjetivos, rupturas: de cambulhada: os signos e as miragens de objetos que eles representam; uma espécie de franciscanismo obriga todas as palavras a se apresentarem, a se apressarem, a tornarem a partir: texto jaspeado, variegado; estamos entulhados pela linguagem como crianças a quem nada fosse jamais recusado, censurado, ou pior ainda: "permitido". É a aposta de uma jubilação contínua, o momento em que por seu excesso o prazer verbal sufoca e oscila na fruição (BARTHES, 2006: 13-14).

Em ensaio intitulado "Da ciência à Literatura", o autor afirma que "da ciência à escritura, há uma terceira margem que a ciência tem de reconquistar: a do prazer" (BARTHES, 2004: 10), e ressalta que o prazer vai além do "gosto", cuja função é agradar, acrescentando que "só o barroco, experiência literária que nunca foi mais do que tolerada em nossas sociedades, pelo menos na francesa, ousou fazer alguma exploração do que se poderia chamar o Eros da linguagem" (BARTHES, 2004: 11). Embora esse espaço criado, de prazer, venha a se distanciar do discurso científico, "é o papel da literatura representar ativamente à instituição científica aquilo que ela recusa, a saber, a soberania da linguagem" (BARTHES, 2004: 11). Nesse sentido, essa sabedoria

\footnotetext{
${ }^{1}$ Roland Barthes foi leitor e crítico da obra de ficção de Severo Sarduy. Em prefácio ao livro Para la voz (1978), de Severo Sarduy, sobre La Playa, Barthes afirma que Sarduy realiza em seus textos uma "festa feliz da linguagem". No original: "Me gustó, pues, La Playa de Severo Sarduy. Quizás yo hubiera deseado que esta fiesta feliz del lenguaje fuera confiada a una dramaturgia de voces y no a una apariencia de teatro. [...] Em La Playa, "se sorprende un texto convirtiéndose en su propia mise em scène, como quería Mallarmé” (BARTHES, 1978: 8).
} 
vem promover a "imprevisão do desfrute", em que a escritura não tem um compromisso com a linearidade, não se preocupa em explicar fatos históricos e tampouco em oferecer certezas, mas sim em interrogar sempre: é a invenção desse espaço, uma terceira margem, que vai proporcionar um efeito estético inovador no texto literário.

Portanto, toda essa introdução sobre o pensamento de Barthes é realizada no sentido de encaminhar a nossa leitura ao encontro da perspectiva teórica de Severo Sarduy, já que este se insere numa tradição literária, seguindo os rastros de Barthes, Bakthin, Kristeva, Compagnon, entre outros, no que se refere aos estudos sobre a escritura, a polifonia, a intertextualidade e a citação. A partir dessa nota, vamos buscar, em Escrito sobre um corpo, uma alusão de Sarduy a uma série de nomes da pintura e da literatura universal, em que o autor afirma, a partir da leitura das obras de Lezama, Dante, Joyce, Proust, Garcilaso, Calderón, Quevedo, Martí, Valéry, Mallarmé, Sade, entre outros, a necessidade de se refletir sobre uma "escritura sem limites" como um

Texto que se repete, que se cita sem limites, que se plagia a si mesmo; tapete que se destece para fiar outros signos, estroma que varia ao infinito seus motivos e cujo único sentido é esse entrecruzamento, essa trama que a linguagem urde. A literatura sem fronteiras históricas nem linguísticas: sistema de vasos comunicantes (SARDUY, 1979: 92).

Em Escrito sobre um corpo, Sarduy analisa o romance Compact, de Maurice Roche, e o considera como um dos primeiros textos que pode ser denominado "nova literatura". ${ }^{2} \mathrm{O}$ ensaísta argumenta que "se Compact insiste nos significantes, no aspecto físico, sonoro, da mensagem, é que essa mensagem em seu reverso, em seu aspecto de significado, é também a de um corpo: a alusão central do livro é um corpo" (SARDUY, 1979: 52, itálico no original):

O travestimento, as metamorfoses contínuas de personagens, a referência a outras culturas, a mistura de idiomas, a divisão do livro em registros (ou vozes) seriam, exaltando o corpo - dança, gestos, todos os significados somáticos -, as características dessa escritura (SARDUY, 1979: 54).

Uma perspectiva nova se abre em Compact, e vem revelar uma história da ficção do corpo e metaforizar as tatuagens de um cego vidente que agoniza: "Compacté um dos livros criadores desse espaço novo, dessa ficção do corpo, do gesto, do erotismo e da morte" (SARDUY, 1979: 54). ${ }^{3}$ Entre outros textos

\footnotetext{
${ }^{2}$ Maurice Roche nasceu em Clermont-Ferrand, França, em 1925. Compact foi o seu primeiro romance, publicado pela coleção Tel Quel, Seuil, em 1966.

${ }^{3}$ Este é o resumo elaborado por Sarduy sobre o romance Compact: "Numa cidade (imaginária; de geografia imprecisa, onde se falam todos os idiomas) um cego agoniza. Um colecionador de peles, médico e japonês,
} 
literários, Sarduy analisa o romance El lugar sin límites, de José Donoso, e afirma que "o travestimento, tal e qual o pratica o romance de Donoso, seria a melhor metáfora do que é a escritura” (SARDUY, 1979: 49). ${ }^{4}$ Logo, entendemos que importa, para Sarduy, ressaltar a aparência do travesti, da personagem Manuela, e, principalmente, o exercício do travestimento:

[...] o que Manuela nos faz ver não é uma mulher sob a aparência da qual se esconderia um homem, mas uma máscara cosmética que ao cair revelasse uma barba, um rosto maltratado e duro, mas o próprio fato do travestimento. Ninguém ignora, e seria impossível ignorá-lo dada a evidência do disfarce, a nitidez do artifício, que Manuela é um bailarino gasto, um homem dissimulado, um capricho. O que Manuela mostra é a coexistência, num só corpo, de significantes masculinos e femininos: a tensão, a repulsa, o antagonismo que entre eles se cria" (SARDUY, 1979: 49, itálicos no original).

No romance referido, de Donoso, Sarduy valoriza a aparência do texto, porque anteriormente esta havia sido considerada pela crítica literária como exterior ao texto. De acordo com Sarduy, "o significado do romance, mais que o travestimento, ou seja, a aparência de inversão sexual, é a inversão em si; uma cadeia metonímica de 'reviravoltas', de desenlaces transpostos, domina a progressão narrativa” (SARDUY, 1979: 46).

A personagem Manuela, conforme a leitura de Sarduy, é comparada a figuras femininas retratadas em certos quadros de Goya, evidenciando o que há de ridículo ou de falso nelas. O autor acredita que, "embora reservado, o sarcasmo aflora na reverente destreza dos retratos de Goya" (SARDUY, 1979: 45). O falso e o risível passam a ser "lidos", a partir, por exemplo, de uma tela do pintor Francisco José de Goya (1746-1828), em que uma dama da corte espanhola aparece retratada de modo exagerado, especialmente nos adereços de cabelo, como o enfeite que se encontra em Marquesa da Solana, (1794-5), um quadro de Goya exposto no Museu do Louvre, que apresenta uma mulher "coroada com uma flor enorme de feltro cor-de-rosa" (SARDUY, 1979: 45). O autor associa o aspecto artificial e falso da mulher retratada ao travesti, ao modo como ele se veste, considerando o exagero dos acessórios e ressaltando ainda o ridículo da figura que pode causar pena, pois, "se a piedade e o riso nos assaltam diante dessas imagens, é porque algo, na panóplia real

e seu assistente, um vistoso travesti, compram a pele do enfermo. A trama do livro é essa espera; essa ficção que metaforiza as tatuagens, reais ou não, da pele do agonizante. Enquanto o cego morre, ou melhor, vêa morte (claro, porque o cego, como era de se esperar, é um vidente) cada vez mais próxima e a recebe com frases sentenciosas, barrocas, ao mesmo tempo profundas e paródicas, o japonês e o travesti giram a seu redor, ambicionando o apergaminhado troféu, as finíssimas texturas da pele, percorridas por inscriçōes, cortadas de pictogramas e hieróglifos de todas as épocas" (SARDUY, 1979: 52).

${ }_{4}^{4}$ José Donoso nasceu em Santiago do Chile, em 1924. Foi romancista, contista, jornalista e professor. O autor publicou o romance El lugar sin límites no ano de 1965. 
que as designa, se assinala como falso" (SARDUY, 1979: 45). Na ótica de Sarduy, "rainha e espantalho, em Manuela o falso aflora, assinala a aversão do postiche: o retrato se converte em borrão, o desenho em rascunho, já que se trata de um travesti, de alguém que levou a experiência da inversão a seus limites" (SARDUY, 1979: 46).

Compreendemos que o indivíduo que se traveste vai além do que dita a tradição ou a convenção social, reavaliando certas dicotomias como, por exemplo: corpo/alma; sagrado/profano; exterior/interior; profundidade/ superfície; natural/artificial. Nesse sentido, o travesti faz uma revisão efetiva de vários conceitos e, a partir de seu comportamento e de sua aparência, pode esvaziar preconceitos inerentes à sociedade em geral. Como já assinalado, o travesti vai além dos limites do próprio corpo, é irrisão da natureza, deseja o jogo, o excesso, e a sua metamorfose tende a ser espetacular. Entendemos que a proposta do travestimento, segundo Sarduy, é a de articular o corpo à escritura - configurando-a como uma linguagem complexa, andrógina, repleta de recursos artificiais. Portanto, essa escritura andrógina se constitui como um corpo em processo constante de transformação e, semelhante ao corpo mutante do travesti, vai ao encontro da teatralidade.

Essa metamorfose que o travesti promove em seu corpo assinala a sua diferença em relação aos outros indivíduos do sexo masculino, porque faz uso de um disfarce, de uma máscara. Em seus ensaios, Sarduy argumenta que a metamorfose do travesti pode ser comparada à metamorfose dos insetos, pois ele faz também uso da camuflagem, nesse caso, "nada assegura que a conversão cosmética - ou cirúrgica - do homem em mulher não tenha como finalidade oculta uma espécie de desaparecimento, de invisibilidade" (SARDUY, 1999: $1268)^{5}$. Conforme o autor, “como os insetos, os travestis são hipertélicos, vão mais além de seus fins, tomam um excesso de precauçóes com frequência fatal. Essa feminilidade suplementária e exagerada os assinala, os denuncia” (SARDUY, 1999: 1268). ${ }^{6}$

A metamorfose é um tema dominante nas narrativas de Sarduy, a exemplo do romance Cobra, e é também em seus ensaios, como em Escrito sobre um corpo e em La simulación, neles destacando as relaçóes entre modelo e cópia e exaltando de modo enfático o corpo e o travestimento da linguagem: "para ele, o modelo desempenha uma função de autoridade e censura e a cópia não pode reduzir-se a ser mera duplicação ou reprodução: deve operar-

\footnotetext{
${ }^{5}$ No original: "nada asegura que la conversión cosmética - o quirúrgica - del hombre en mujer no tenga como finalidad oculta una especie de desaparición, de invisibilidad” (SARDUY, 1999: 1268).

${ }^{6}$ No original: "como los insectos, los travestis son hipertélicos: van más allá de sus fines, toman un exceso de precauciones con frecuencia fatal. Esa feminidad suplementaria y exagerada los señala, los denuncia” (SARDUY, 1999: 1268).
} 
se uma distância, a da paródia, da contrafeitura" (CIVIL, 1999: 1669). ${ }^{7}$ Segundo Sarduy, o travesti exercita uma prática de fazer-se passar por outro, a de transformar-se até parecer uma mulher, como aquelas retratadas nas telas de Goya:

O travesti não imita a mulher [...] o travesti não copia: simula, pois não há norma que convide e magnetize a transformação, que decida a metáfora: é a inexistência do ser mimado o que constitui o espaço, a regiâo ou suporte dessa simulação, dessa impostura arrumada: aparência que regula uma pulsação goyesca: entre o riso e a morte (SARDUY, 1999: 1267). ${ }^{8}$

Portanto, a simulação e a metamorfose do corpo da personagem travesti deverão ser articuladas às transformaçóes ocorridas no romance Cobra, de Severo Sarduy, uma escritura que se apresenta como uma das mais originais da literatura latino-americana na contemporaneidade.

No romance Cobra, o culto à ambiguidade permeia toda a narrativa, através das cenas em que as personagens se preparam para a apresentaçáo no teatro e da repetição de situaçôes e ambientes. Na ficção de Sarduy, a personagem principal é denominada Cobra, um travesti entre outros que o texto comporta exageradamente. É desse modo que, simultaneamente, a identidade, a sexualidade e a própria linguagem vão sendo confrontadas na narrativa. Há um excesso não somente em relaçáo à multiplicidade de cenas teatrais, assim como quanto ao número de citaçóes, de intertextualidades, de metáforas e metonímias disseminadas numa infinidade de ornamentos e detalhes.

Ao analisarmos Cobra, encontramos vários sentidos para o título do romance: é uma serpente da Índia, insaciável, fálica, que se enrosca sobre si mesma para morder a própria cauda; Cobra é também um anagrama de um grupo de pintores (Appel, Aleschinsky, Corneille, Jorn) que provém de COpenhague, BRuxelas e Amsterdã, respectivamente: COBRA. E, além dessas acepções, Cobra permite outras significações, como, por exemplo, uma referência a elementos da mitologia cubana e, nesse sentido, o travesti do Teatro Lírico de Bonecas pode ser inserido também no espaço metafórico cubano. Em prefácio ao livro Barroco, de Severo Sarduy, José Manuel de Vasconcelos ressalta que Cobra é ainda um "anagrama de Baroc":

\footnotetext{
${ }^{7}$ No original: "para él, el modelo desempeña una función de autoridad y censura y la copia no puede reducirse a ser mera duplicación o reproducción: debe operarse una distancia, la de la parodia, de la contrahechura" (CIVIL, 1999: 1669).

${ }^{8}$ No original: "El travesti no imita la mujer [...] el travesti no copia: simula, pues no hay norma que invite y magnetice la transformación, que decida la metáfora: es más bien la inexistencia del ser mimado lo que constituye el espacio, la región o el soporte de esa simulación, de esa impostura concertada: aparecer que regula una pulsación goyesca: entre la risa y la muerte (SARDUY, 1999: 1267).
} 
Cobra é o romance de uma obsessão, a metamorfose - obsessão barroca que anima as personagens através dos jogos verbais ininterruptos, narrativa sem centro, num equilíbrio de oposiçôes, escrita hermafrodita, culto da ambiguidade (Cobra: serpente das Índias ou phallus, grupo de pintores ou anagrama de cidades europeias Co(penhaga) $\mathrm{Br}$ (uxelas) $\mathrm{A}$ (msterdão) - tudo isso é cobra, que é mais do que tudo anagrama de Baroc (VASCONCELOS, 1988: 12).

Essa narrativa obsessiva em relação à metamorfose é tecida a partir de uma história real, da morte de um travesti conhecido como Cobra, que se apresentou no Cabaret Carroussel em Paris nos anos 1960. Sarduy, ao saber da notícia da morte do travesti, começa a escrever o seu romance homônimo. Em entrevista a Danubio Torres Fierro, Sarduy elucida o motivo pelo qual decidiu escrever o romance:

O que me moveu, quase compulsivamente, foi uma frase ouvida numa praia: "Cobra morreu em um acidente em Fujiyama". Todo o livro pode ser, de modo muito transparente, o desenvolvimento dessa frase, seu sacudimento, como diziam os surrealistas. Cobra existiu: era um travesti do Carroussel, de Paris, que efetivamente faleceu num acidente no Japão quando a troupe regressava de uma série de apresentações no país. Sua vida e sua transformação estão em outro ponto, e também a de seu duplo, um Cobra-macho que é um blousonnoir e que tem muito a ver com os que aparecem no filme Scorpio Rising, de Kenneth Anger, ainda que com uma diferença: os de Cobra sempre "cortam" o que se pode transformar em enfático com um ato antirritual: o sangue de uma cerimônia sádica pode tornar-se ketchup, e o sêmen da mesma cerimônia, iogurte. Cobra, que é também um anagrama de Copenhague, Bruxelas e Amsterdã, trata de anular essa contradição sexual, esse par de opostos, creio que por isso tive que concluí-la no lugar onde, por excelência, os opostos se anulam e desaparecem, isto é, em um mosteiro tibetano (SARDUY, 1999: 1818, tradução minha). ${ }^{9}$

\footnotetext{
${ }^{9}$ No original: "Me movió, casi compulsivamente, una frase escuchada en una playa: 'Cobra murió en jet en el Fujiyama'. Todo el libro puede ser, de modo muy transparente, el desarrollo de esa frase, su sacudimiento, como decían los surrealistas. Cobra existió: era un travestí del Carroussel, de París, que efectivamente se mató en un accidente en Japón cuando la troupe regresaba de una gira por ese país. Está su vida, su transformación en otra cosa, y también la de su doble, un Cobra-macho que es un blouson-noir y que tiene mucho que ver con los que aparecen en la película Scorpio Rising, de Kenneth Anger, aunque con una diferencia: los de Cobra siempre 'cortan' lo que puede volverse enfático con un acto anti-ritual: la sangre de una ceremonia sádica puede volverse ketchup, el semen de la misma ceremonia, yogurt. Cobra, que también es un anagrama de Copenhague, Brucelas e Amsterdam, trata de anular esa contradicción sexual, ese par de opuestos; creo que por eso tuve que ir a concluirla en el lugar donde, por excelencia, los opuestos se anulan y desaparecen, es decir, en un monasterio tibetano (SARDUY, 1999: 1818).
} 
Nessa obra de Sarduy, tudo se torna exuberante, num delírio de ambiências em que encontramos imagens, tempos e espaços sobrepostos, além de provocaçóes feitas diretamente ao leitor através de uma escritura que reflete sobre o universo do travesti, sobre o corpo e sobre a história. Em Cobra, observamos, na constante transformação dessas personagens, a troca de identidade e o seu jogo incessante com a realidade, destacando o desejo de liberdade, de revolucionar códigos morais rígidos através do seu travestimento: Cobra é uma personagem que cria a sua própria ordem pela via do corpo e da transexualidade.

Desse modo, essas transformaçóes da personagem vão ocorrendo ao longo da narrativa, como em processos de anamorfose, em função especialmente da "energia da conversáo", obtida por meio do movimento de transformação da própria personagem travesti e concentrada no processo de transformação do seu corpo, movimento que vai do ser ao parecer, importando, para Cobra, afirmar a sua essência através da simulação. Essa energia se revela pelo uso de artifícios como a preparação de roupas, maquiagem, tatuagem, chegando à mutação radical da personagem.

Cobra quer metamorfosear-se até atingir uma forma divina (ou até encontrar a morte), este é o ideal da personagem espelhado no próprio texto, no qual o leitor se insere, participando de suas recorrências e volutas, entre diversas citaçóes e intertextualidades. Na passagem em que a personagem Senhora conversa com um "teólogo esclarecido" (SARDUY, 1975: 48) sobre a cirurgia para a troca de sexo de Cobra, o Padre se mostra contrário à mutação da personagem, e sem interesse em alongar a discussão, afirma: "chega de arabescos, passemos ao assunto medular, ao miolo teórico da troca" (SARDUY, 1975: 48). Em resposta aos argumentos do Padre, reproduzimos a resposta da Senhora, a qual, ao defender a mudança de sexo de Cobra, cita o livro teórico Escrito sobre um corpo, cuja ênfase se encontra no corpo, e este como metáfora para a escritura, tratando-se, enfim, de uma referência teórica do próprio autor do romance. No diálogo, o Padre se encontra perplexo diante do desejo de mudança de sexo da personagem:

- Que desatino, minhas filhas! [Senhora, Cobra e Pup] e: de que mentes rústicas e desbaratadas herdais tâo lamentável invençãa? [...] E, uma vez convertida em seu contrário e enterradas devidamente (como ordena a Igreja que se faça com os dedos e até com as falanges soltas) as sobrantes partes pudentes, no Dia do Juízo, com que cara e natureza aparecerá a destinada [Cobra] ante o Criador e como a reconhecerá este sem os atributos que a sabendas the deu, remodelada, refeita, e como um circunciso terminada à mão? (SARDUY, 1975: 48).

A referência ao texto teórico de Sarduy é encontrada na resposta da 
Senhora ao Padre, a qual contempla uma caveira e um relógio de areia sobre um livro (o que nos remete ao motivo Vanitas, a vaidade como contraste aos símbolos da transitoriedade da vida, como retratado em tela do célebre pintor Hans Holbein). A Senhora argumenta:

- Me espanta que você pense assim - replicou a Teórica [ a Senhora] -: o corpo, antes de atingir seu estado perdurável - e contemplou, com vistosa compaixão, uma caveira e um relógio de areia disposto sobre um fascículo fechado, num ângulo da mesa do pároco - é um livro em que aparece escrito o ditame divino; por que, em um caso como o aqui presente, em que claramente no Escrito sobre um corpo escapou um embora nímio embaraçoso erro, não emendar o desacerto e dar cabo da vergôntea errada, como entre as crianças, quando punge, cauteriza-se um dedinho marginal ou uma moleja? E se foi precisamente a este vilarejo - continuou a Ínclita - aonde trago à colação, reverendo, este a seus olhos herético remédio, foi porque sei estar entre peritos dissecadores e que tanta destreza, considero, em muito se aplica às excrescências, que assim batizaria eu estas inconsequentes dádivas da natureza, e malformaçóes dos vivos (SARDUY, 1975: 49).

Esse transformação radical a que se submete a personagem Cobra se constitui como em processo de anamorfose, durante um diálogo em que se questiona o sagrado, a Igreja, a ordem e a própria natureza. A personagem Senhora cita o texto teórico de Sarduy, Escrito sobre um corpo (que trata de temas como erotismo e travestimento, entre outros, cuja ênfase é dada ao corpo), um livro composto de diversas análises de obras literárias em que se destacam personagens travestis. Portanto, segundo a personagem, a "Teórica", é nesse livro que aparecem escritos os mandamentos divinos, isto é, a pulsão para o erotismo e para a liberdade de si e do corpo. Em ensaio sobre o corpo e sobre a dissimulação, Guy Scarpetta aborda esse tema, refletindo sobre questóes como a identidade sexual e a irrisão da natureza do travesti:

De que verdade intolerável o travesti é portador? Do fato de que a identidade sexual, longe de ser um fato da "natureza", é sempre um efeito do simbólico. Verdade que o travesti encarna no drama ou na irrisáo, pouco importa, em todo o caso num reino do aparente que náo deixa lugar a nenhuma verdade de fundo, natural ou orgânica. Pois, se isto é um pouco freudiano, está claro que fazer "teatro", querer "representar um papel", é, profunda e inconscientemente, querer mudar de sexo (SCARPETTA, 1978: 10, tradução minha)..$^{10}$

\footnotetext{
${ }^{10}$ Palavras de Guy Scarpetta em ensaio sobre o texto para teatro intitulado La Playa, de Severo Sarduy. No original: "De qué verdad intolerable es portador el travesti? Del hecho de que la identidad sexual lejos de ser un hecho de la 'naturaleza', es siempre un efecto de lo simbólico. Verdad que el travesti encarna en el drama o en la irrisión, poco importa, en todo caso en un reino de lo aparente que no deja lugar a ninguna verdad de fondo, natural u orgánica. Pues si se es un poquito freudiano, está claro que 'hacer teatro', querer 'representar un papel', es, profunda e inconscientemente, querer cambiar de sexo" (SCARPETTA, 1978: 10).
} 
Na narrativa, Cobra é uma personagem que rejeita o seu corpo masculino, por não se reconhecer em sua própria natureza, e almeja ser outro, transformar-se em outro, cujo corpo é feminino, chegando até mesmo a desejar a castração do seu órgão sexual. Como visto, se seguíssemos apenas por essa linha, o romance poderia ser lido como a história da metamorfose da personagem Cobra, em que se revelariam as suas mutaçóes. Cobra é essa metamorfose e muito mais, abrangendo várias histórias numa narrativa não linear, fragmentária, cuja espessura comporta várias camadas de significaçâo. Em meio a uma superposição de texturas, a personagem Cobra exibe diferentes formas (ou escamas), troca de pele, podendo ser simultaneamente (não necessariamente nesta ordem): o travesti do Teatro Lírico de Bonecas na Paris dos anos 1960; a sua própria redução na forma da Anã Branca (Pup); candidato à lâmina castradora do Dr. Katzob; um dos componentes de um grupo de motociclistas (blusons noirs), os quais viajam de Saint-Germainde-Prés com a intenção de realizar um ritual de iniciação (sexual/erótica) num bosque de salgueiros; membro de um grupo de lamas tibetanos que se assemelham a hippies, usuários de drogas em Amsterdá; um turista ávido de tantrismos, leitor de Octavio Paz.

O romance é estruturado em duas partes que são entrelaçadas, como se pretendesse formular uma proposta de diálogo entre o Oriente e o Ocidente. No decorrer desse "diálogo", conhecemos a história de Cobra e da sua compulsão pela transformação, a paixão pelo absoluto e a obsessão pela perfeição física. Ao longo de toda a narrativa, tudo se relaciona ao travesti Cobra, mas outras personagens se destacam, como a Senhora, a Aná Branca (Pup), as quais ressaltam a figura do duplo (motivo que representa simultaneamente a imagem ideal de si mesmo e o reflexo daquela que mais o desagrada); Eustáquio (o indiano maquiador); Tigre, Tundra, Escorpião e Totem (a trupe da protagonista), personagens que vivenciam o universo dos travestis. Todas essas personagens, por suas características e pelo modo como se apresentam nos dois relatos entrelaçados (Partes I e II, esta última salientando a trajetória erótica de Cobra), têm o hábito de transgredir o que determina a convenção social (a tradição), e procuram livremente criar o seu próprio espaço no mundo.

O desejo de transformação da personagem Cobra pode ser identificado a partir de uma indagação da própria personagem: "Deus meu [...] - por que me fizeste nascer se não era para ser absolutamente divina?” (SARDUY, 1975: 7). Numa tentativa de redução de seus pés, os quais a personagem chama de "rebeldes", passa a promover várias açóes a fim de corrigi-los, reduzi-los, ainda que para isso precise suportar dor e sofrimento: "Desde o amanhecer, metidos em formas, aplicava-lhes compressas de pedra-ume, castigava-os com banhos sucessivos de água fria e quente. Apertou com mordaças, submeteu- 
os a mecânicas grosseiras" (SARDUY, 1975: 7). No decorrer da narrativa, a personagem repete o mesmo procedimento de tortura dos seus pés:

Âncoras planas a fixavam na terra: deixavam a desejar os pés de Cobra, "eram seu inferno". Encerrava-os em formas desde o amanhecer, aplicava-lhes compressas de pedra-ume, castigava-os com banhos sucessivos de água fria e quente. Fabricou, para metê-los, armaçóes de arame, cujos fios encurtava, retorcendo com alicates; apertou com mordaças, submeteu-se a mecânicas grosseiras; depois de lambusados com goma-arábica, cercou-os de ataduras; eram múmias, bebês de medalhóes florentino.

Intentou curetagens.

Recorreu à magia.

Caiu no determinismo ortopédico (SARDUY, 1975: 16-17).

Após diversas tentativas para a mudança da forma de seus pés, Cobra tomou uma medida extrema, uma atitude de inversão, revolucionária: "A rainha tinha se pendurado no teto, pelos pés, enforcada ao contrário: correntes de cabacinhas a penduravam pelo tornozelo ao suporte de uma lâmpada. Era um morcego entre globos de vidro opalescente e cálices de quartzo" (SARDUY, 1975: 18). Essa transformação de Cobra em morcego apavorou a Senhora e o maquiador, que, ao encontrá-la, providenciaram a retirada da personagem do teto. Cobra "tinha perdido o sentido do equilíbrio e, parecia, também o equilíbrio dos sentidos. Como a toda revolução, sucedeu a esta um regime de sinapismos draconianos". Porém, "Pouco cederam os pés [...] trabalhosamente se deslocava Cobra em cena” (SARDUY, 1975: 19).

Como num ritual sagrado, os cuidados da personagem com a sua transformação para a apresentação no teatro durava cerca de seis horas, quando Cobra se tornava a "rainha do Teatro Lírico de Bonecas" (SARDUY, 1975: 7), momento em que era contemplada e adorada por seus admiradores:

Às seis começava a transformar-se para o espetáculo das doze; nesse penoso ritual, cada enfeite tinha seu mérito: as pestanas postiças e a coroa, os pigmentos, que não podiam ser tocados pelos profanos, as lentes de contato amarelas - olhos de tigre - os pós-de-arroz das grandes plumas brancas. Mesmo fora de cena, uma vez pintados e metidos em seus trajes, a Rainha era obedecida, e fugiam pelos corredores ou se encerravam nos armários embutidos e saíam os criados caiados de farinha à aparição bigoduda de um Demônio [a Senhora] (SARDUY, 1975: 8).

[...] Mas o que merece menção é que os ardentes apaixonados de Cobra não se assanhavam senão para adorá-lo de perto, para permanecer uns instantes em sua muda contemplação. Um londrino, pálido importador de chá, trouxe-lhe, certa noite, três tamborins, para que a seu ritmo, ela, carregada de pulseiras, de 
címbalos, de luzes e arcos, calcasse os pés, como Durga ao demônio convertido em búfalo. Alguns, serenos, pediam para beijar-lhe as mãos; outros, mais perturbados, para lamber suas roupas; uns poucos, dialéticos, se entregavam a ela, suprema irrisão do yang (SARDUY, 1975: 10).

A personagem Senhora tem uma função importante no teatro, pois é a responsável por toda a organização do espetáculo, passando o dia às voltas com todos os preparativos: o trabalho na cozinha, os cuidados com os cabelos, as perucas, a maquiagem das atrizes/estrelas. No entanto, sua aparência contrastava com a das atrizes em cena: a "Senhora deslizava em chinelos de Macaco Sábio, dispondo os aparatos que estruturavam aquele espaço decroché, aquela heterotopia - casa de pensão, teatro ritual e/ou fábrica de bonecas, puteiro lírico" (SARDUY, 1975: 9). Ressaltamos que, nesse teatro, Cobra é uma boneca muito especial para Senhora, a preferida entre Dior, Sontag e Cadillac, por exemplo:

Cobra era seu melhor sucesso, sua "figa de Guiné". Apesar dos pés e da sombra - confira capítulo V - era a preferida dentre as outras bonecas, terminadas ou em processo. Desde o amanhecer, escolhia suas roupas, escovava suas perucas, arrumava sobre as poltronas vitorianas casacas indianas com galóes de ouro, gatos vivos e de pelúcia; ocultava entre almofadas, para que a surpreendessem à hora da sesta, acrobatas de corda e encantadores de serpente que, ao serem tocados punham em marcha uma Valsa sobre as ondas, com gorgeios de barítono, de flautim de lata (SARDUY, 1975: 9).

Por oportuno, recorremos a Mikhail Bakhtin, em Problemas da Poética de Dostoiévski, o qual inaugura, na literatura, o conceito de romance polifônico e de carnavalização a partir da sua análise das obras de Dostoiévski. A sua teoria colabora para o esclarecimento do fenômeno denominado "carnaval" tanto como prática social e cultural quanto como linguagem, esta cheia de motivaçóes e de sentidos múltiplos, que se vão ressignificando ao longo do tempo. Nesse sentido, a carnavalização pode ser compreendida como fenômeno cultural ou como gênero literário. Segundo Bakthin,

É a essa transposição do carnaval para a linguagem da literatura que chamamos carnavalização da literatura. O carnaval é um espetáculo sem ribalta e sem divisão entre atores e espectadores. No carnaval todos são participantes ativos, todos participam da ação carnavalesca. Não se contempla e, em termos rigorosos, nem se representa o carnaval mas vive-se nele, e vive-se conforme as suas leis enquanto estas vigoram, ou seja, vive-se uma vida carnavalesca. Esta é uma vida desviada da sua ordem habitual, em certo sentido uma "vida às avessas", um "mundo invertido" ("monde à lenvers") (BAKTHIN, 1997: 122). 
Cobra se apropria desse carnaval porque tem uma vida desviada, invertida e às avessas, assim como passamos a vivenciar, como leitores, a carnavalização da escritura Cobra, de Sarduy. No palco de Cobra não há regras nem interdiçôes, tudo é permitido, inclusive o profano, o grotesco e o obsceno, é o espaço onde acontece exatamente o contrário do que dita a ordem, a cultura oficial, que tende a cercear os indivíduos. Portanto, nesse romance, a carnavalização agrega um conjunto de metamorfoses, de travestimentos, considerando-se a afirmação da fantasia e da inventividade, e acima de tudo, do ritual, no qual ocorrem as transformaçóes mais significativas.

Toda a revoluçấo promovida pelo travesti Cobra pode ser encontrada em seu corpo, como nas palavras do Mestre, pintor que retrata Pup em "PORTRAIT DE PUP EN ENFANT", as quais expressam a relação entre corpo e escritura, de cada gesto que é capaz de ser percebido como os fios da trama de um texto literário. O Mestre empunhava um "pêndulo semiológico" que tinha a pretensão de purificar o corpo da cópia reduzida de Cobra, de retirar de dentro de Pup as garrafadas chinesas que ela havia ingerido. $\mathrm{O}$ Mestre ("Mago"), "depois de tomar fôlego, inaugurou uma oração gongórica" (SARDUY, 1975: 37), dizendo que "tudo consiste em punçar os centros, quer dizer, os do crescimento centros vitais, os do desenvolvimento e expansão... E, abrindo a mão direita lançou ao ar, com a seriedade de quem joga ioiô, o cone de cobre" (SARDUY, 1975: 37). O corpo de Cobra recebe a inscrição de flores, as quais se bifurcam continuamente, desdobrando-se em fios:

O Mestre - os olhos da Senhora, tão fascinada estava com o movimento oscilatório, deslocavam-se de um lado para o outro: negrinho de relógio veneziano: $\mathrm{O}$ corpo, minha estimada, inscreve-se em uma rede... - subiu o pêndulo até a cabeça de Pup - seis flores marcam a linha média... - e o foi descendo, solene, como se as rotaçóes traçassem as voltas de uma serpente em torno da coluna vertebral -. Das flores, em todos os sentidos, bifurcando-se, entretecendo-se, partem fios... O homem - sobre o sexo de Pup o pêndulo se deteve - é opaco, a madeixa dourada. Uma orla escura, uma linha contínua, negra, limita a figura, que atravessam fibras incandescentes... - o cone brilhante vacilou, começou a girar em sentido contrário -. Cada um de seus gestos, por mais instantâneo ou imperceptível que seja, repercute na trama inteira, como nos flagelos o susto de um peixe... Aqui, está vendo, aqui é preciso alterar uma flor, uma corola nervosa, é preciso estimular um plexo, para que viva... não sei como explicar... certos seres quase invisíveis, quase inclassificáveis, entre os animais e as plantas, quando espetados, crescem... Dê-me as agulhas (SARDUY, 1975: 38).

A personagem Pup (duplo de Cobra) evidencia essa metamorfose do corpo de Cobra, pois é espetada a fim de que cresça, para que sobreviva. Das flores tatuadas no corpo de Pup partem fios que se entrecruzam, assim como 
acontece na trama do romance. Pup, após sofrer várias espetadas de agulhas, além de mais torturas que lhe foram impostas, revolta-se contra a Senhora, afinal, tinha perdido o riso, a cor, os lábios estavam partidos, a moleira aberta, parecia "uma facínora, uma bruxa do teatro popular birmanês, e tudo por amor à arte" (SARDUY, 1975: 43). Nesse diálogo entre Pup e a Senhora, esta responde ao comentário de Pup: "- Momentânea rainha - respondeu a Senhora -, quâo voraz é tua lepra!” (SARDUY, 1975: 43). Pup segue por um corredor em direção ao seu quarto, semelhante a uma "Mortazinha gótica", que, antes de deitar-se, canta a canção "Blue Moon" (uma das várias referências à cultura Pop no texto). ${ }^{11}$ Pup

Não chorou. Adotou o desdém de uma Mortazinha gótica arrastando seu féretro; precedia-a um séquito sarmentoso, nos azulejos, onde iam se refletindo clepsidras e gadanhas, sua passagem era um desfile de esqueletos, uma festa de alegorias macabras.

Trancou-se dando duas voltas na chave.

Despiu-se ante o espelho.

Meteu a peruca de Marlene e duas gardênias de pano entre os cabelos. Claro que tinha crescido. Era uma soberba mulherona, um pouco aquosa, é verdade, e mais para o trivial, com exceção de um detalhe, que descobriu muito mais tarde, quando ia deixar de mirar-se no espelho: fechava os olhos de baixo para cima.

Era de tanto dormir com a cabeça mais baixa do que os pés.

Provou um por um todos os vestidos de rainha.

Cantou Blue Moon.

Deitou-se muito rechonchuda (SARDUY, 1975: 43).

$[\ldots]$

Ao amanhecer, ainda estava viva, embora - a Beleza é efêmera - já estivesse encolhendo (SARDUY, 1975: 44).

Enquanto Pup sofria todas essas transformaçóes em seu corpo, indo inclusive deixar de mirar-se no espelho em virtude da inversão do piscar de olhos porque fechava-os de baixo para cima (além do uso de peruca e de flores de pano na cabeça), Cobra havia partido "para a Índia nos braços de um boxeador guachinango deixando nos da aparvalhada celentina a travestida de raio muito pequeno [Pup é aqui comparada a uma estrela de luz fraca, a uma aná branca] que havia alcançado o final de sua evolução" (SARDUY, 1975: 33-34). No final desse capítulo, "quando Cobra voltou da Índia encontrou-a

\footnotetext{
${ }^{11}$ Emir Rodríguez Monegal, ao analisar Cobra em "Sarduy: las metamorfosis del texto", observa as alusóes, citaçóes e paródias referentes à cultura popular, como o uso frequente de marcas de fábricas (Shell, CocaCola, Life), a referência às estrelas de cinema (Garbo, Marlene e Veronica Lake) e aos músicos como Beatles e Ravi Shankar (RODRÍGUEZ MONEGAL, 1999: 1739).
} 
tão raquítica como de costume. Do que lhe contaram não acreditou em nada" (SARDUY, 1975: 46).

Cobra se prepara para submeter-se a uma operação de transformação, com o intuito de "jogar fora o que está sobrando" (SARDUY, 1975: 56), despojando-se de seu órgáo sexual por considerá-lo supérfluo. Vai procurar o Doutor Ktazob, seguindo a indicação de outro travesti, Cadillac, que diz: "Ah, e vai recomendada por mim, beleza; lhe deixará bem talhada. Mas reserva para mim, isso sim, a estreia. Risada. Palmada nas cadeiras. Puxou a porta. Cobra deixou-se cair na cama. Sua cabeça era um caos" (SARDUY, 1975: 56).

No episódio em que acontece a castração de Cobra, "A conversão", a Senhora sugere também que o travesti procure o referido Doutor, e a adverte quanto às consequências da atitude que está na iminência de tomar: "Mais que no de teu delírio, olha-te no espelho das outras: fogem cabisbaixas, como se acabassem de perder um rubi na calçada, para que o cabelo lhes cubra, como a Veronica Lake, ou a leprosas, o rosto" (SARDUY, 1975: 57). Além disso, passa a oferecer-lhe duas versões para o desfecho de tamanha intervenção cirúrgica: na primeira, a ilusão de que Cobra acordaria como Greta Garbo; na segunda, a personagem sofreria todo tipo de tortura e, ao final, um cão amarelo viria lamber seus pés. Essas duas versóes da Senhora para um mesmo acontecimento remetem à proposta ambígua do texto, de ludicidade, aliada às citaçóes do autor (antes, a referência à atriz de cinema Verônica Lake e, neste fragmento, à Greta Garbo):

Vais a Ktazob, filhinha, tão despreocupada como se fosses ao dentista. Crês que, passada a benigna extraçáo, sem maiores tormentos que umas intemperanças, com um ramo de orquídeas birmanesas, um suco de laranja azeda e a certidão de alto, ao cair da tarde uma enfermeira biscainha trará um espelho de mão, onde, mais do que tua imagem, sobre fundos crepusculares contemplarás, com sua palidez de tísica convalescente, em close-up a Greta Garbo... Desce dessa nuvem: depois da carnificina e se a aguentas, espera-te um aguaceiro de picadas, depilaçốes e curativos, cera nos seios, vidros nas veias, vapores de cogumelos no nariz e leveduras verdes pela boca. Tapa os olhos com uvas. Com bolas Quies os ouvidos. Um cachorro amarelo vai lamber teus pés (SARDUY, 1975: 57).

A castração de Cobra aparece em primeiro plano, quando Ktazob informa-lhe sobre o procedimento cirúrgico: “- Saiba que não uso anestesia. É capital, ou minha prática, pelo menos, assim o entende, que o mutante, no trânsito, não perca a consciência" (SARDUY, 1975: 59). Como já apontado anteriormente, Cobra passará por sucessivas e às vezes simultâneas metamorfoses pela intervenção da tatuagem, da pintura, da troca de vestimenta, de vários enfeites e por último pela lâmina do Dr. Ktazob, que fará incisóes 
na carne, no falo de Cobra, membro que vem a ser extraído de seu corpo. O médico é chamado também de "Alterador", o qual "traz o rosto descoberto, liso, claro, impassível, frio como uma cebola branca recém-lavada; um pano oculta o dos Instrutores, encerrados em negro. Cobra jaz nua numa mesa de metal; braços e pernas abertos; Pup sobre uma placa de amianto" (SARDUY, 1975: 63). É o momento da cirurgia da inversão, momento em que compreendemos que Pup, o duplo de Cobra, é quem se submete à castração, pois esta personagem foi orientada a passar a dor para a outra:

[...] Pup grita. Salpicaduras. Grande gota de tinta espessa fogem para os lados do corpo de Cobra. Relâmpago. Ruptura. Ramos vermelhos que descem bifurcando-se, rápidos, pelos lados de um triângulo - o vértice arrancado -, sobre a pele branca das coxas, pela superfície de níquel, contornando as cadeiras, entre o tronco e os braços, encharcando-se nas axilas, filetes velozes sobre os ombros, grudando-lhe o cabelo: dois jorros de sangue, até o chão (SARDUY, 1975: 64).

Ao término da cirurgia de conversão de Cobra, a enfermeira oferecelhe um espelho em que ela se contempla demoradamente e, após, devolve-o, dizendo: "Viu alguma vez a 'A Dama das Camélias'?" (SARDUY, 1975: 67). O caráter lúdico de toda a história sobre a castração da personagem se revela nesse desfecho em que a citação de Cobra pode nos remeter ao romance $A$ Dama das Camélias, de Alexandre Dumas Filho e/ou à Greta Garbo, atriz que protagonizou a adaptação do romance homônimo para o cinema.

No episódio seguinte, "Que tal?", que se segue à lamina castradora de Ktazob, Cobra sai do metrô, atravessa a rua, sente "o ar rançoso dos botecos, a fumaça da carne queimada, do álcool azedo e a gordura: o ácido da chuva a vai trabalhando, roendo" (SARDUY, 1975: 70). A personagem está fragilizada, e o ambiente apresentado não a favorece, ao contrário, deixa-a bastante insegura. Procura um espelho onde se vê desmanchando por dentro (Cobra chora) e por fora, pois o cabelo e a maquiagem vão-se desmoronando. Até certo ponto, o narrador passa a descrever o sofrimento de Cobra, que busca proteção numa marquise, pois a personagem se encontra fragilizada diante do olhar incisivo das pessoas, quando, por fim, cede-lhe a voz: "Me seguiram", diz Cobra. A curiosidade das pessoas perturba a personagem, que é comparada agora à atriz Theda Bara, até que uma senhora idosa, pintada de modo semelhante à maquiagem usada por Cobra, aponta para a personagem, identificando-a com um homem:

Refugiou-se na marquise de um teatro. [...] ante um espelho relampejante, pode apreciar os desgastes: a severa engenharia do penteado estava se desmoronando por todas as partes, os rabichos - cais vencidos -] jorravam pintura, sobre 
o rosto caíam laços em tripas, uma grande mancha negra lhe caía desde os olhos, a sombra azul emergia ao redor da boca.

Saiu chorando.

Um menino olhou fixo para ela.

Um velho se lembrou de Theda Bara.

[...] As pessoas foram se juntando em redor dela.

Me seguiram.

Me fustigaram.

Me cercaram contra um muro.

Lantejoulas negras bochechas, anéis luxuriosos nos dedos, flecha de brilhantes sobre o pompom de cãs, do grupo surgiu uma octogenária toda pintada. Aproximou-se bambaleando, cantando, fanhosa, em falsete: - Que tal? - me perguntou, imitando-me.

Com o dedo indicador ossudo bem perto dos meus lábios, gritou:

- É ele (SARDUY, 1975: 70-71).

Essa imagem sofrida de Cobra, que chora, com o rosto borrado pela maquiagem exagerada (decompondo-se e desvelando o homem que existe por detrás da máscara que cobre seu rosto, do seu penteado e das suas roupas), conta um pouco da história desse travesti, cuja existência ambígua é caracterizada por seu desejo de romper qualquer ordem instituída. Nesse sentido, considerandose a coexistência de gêneros em um só corpo, o travestimento do corpo de Cobra passa a ser determinado por sua ambivalência, e o mesmo pode ocorrer com o corpo do texto, o qual pode modificar constantemente a sua aparência, transformando a linguagem num "espaço de conversóes, de transformaçóes e disfarces” (SARDUY, 1979: 48).

\section{Referências bibliográficas}

BAKHTIN, Mikhail. Problemas da poética de Dostoiévski. 2. ed. rev. Tradução do russo por Paulo Bezerra. Rio de Janeiro: Forense Universitária, 1997.

BARTHES, Roland. O prazer do texto. 4. ed. Tradução de J. Guinsburg. São Paulo: Perspectiva, 2006.

.O rumor da língua. 2. ed. Prefácio de Leyla Perrone Moisés. Tradução Mario Laranjeira. Revisão da tradução Andréa Stahel M. da Silva. São Paulo: Martins Fontes, 2004.

. "Prefácio". In: SARDUY, Severo. Para la voz. Madrid: Fundamentos, 1978: 7-8. 
CIVIL, Françoise Moulin. "Invención y epifaníadel Neobarroco: Excesos, desbordamientos, reverberaciones". In: SARDUY, Severo. Obra Completa. ed. crítica de Gustavo Guerrero y François Wahl (Coords.). Madrid: ALLCA XX/ Scipione Cultural, 1999: 1649-1678.

RODRÍGUEZ MONEGAL, Emir. "Sarduy: las metamorfosis del texto". In: SARDUY, Severo. Obra Completa. ed. crítica de Gustavo Guerrero y François Wahl (Coords.). Madrid: ALLCA XX/Scipione Cultural, 1999: 1734-1750.

SARDUY, Severo. Obra Completa. ed. crítica de Gustavo Guerrero y François Wahl (Coords.). Madrid: ALLCA XX/Scipione Cultural, 1999. 2 vol.

. Barroco. Tradução de Maria de Lurdes Júdice e José Manuel de Vasconcelos. Lisboa: Veja Universidade, 1988. - Escrito sobre um corpo. São Paulo: Perspectiva, 1979. . Para la voz. Madrid: Fundamentos, 1978.

. Cobra. Tradução de Gerardo Mello Mourão. Rio de Janeiro: José Álvaro Editor, 1975.

SCARPETTA, Guy. "Prefácio". In: SARDUY, Severo. Para la voz. Madrid: Fundamentos, 1978: 9-12.

VASCONCELOS, José de Manuel. “Prefácio”. In: SARDUY, Severo Barroco. Tradução de Maria de Lurdes Júdice e José Manuel de Vasconcelos. Lisboa: Veja Universidade, 1988: 7-17.

Maria Cristina Chaves Carvalho. Pesquisadora de Pós-Doutorado na Universidade Federal de Espirito Santo (Bolsista FAPES). Tem Doutorado em Letras/Literatura Comparada pela Universidade Federal Fluminense, Mestrado em Letras pela Pontifícia Universidade Católica do Rio de Janeiro e Graduação em Letras (Português-Literaturas) pela Universidade Federal do Rio de Janeiro. Atualmente desenvolve um projeto de pesquisa sobre Literaturas Africanas.

E-mail: mcriscar@hotmail.com 